\title{
Filtered Gender Diversity Pathways for Domestic and International Doctoral Graduates of United States Electrical Engineering (EE), Computer Engineer- ing (CompE) and Electrical and Computer Engineering (ECE) Programs
}

\section{Prof. Keith J Bowman, Illinois Institute of Technology}

Keith J. Bowman became Professor and Chair of the Department of Mechanical, Materials and Aerospace Engineering at Illinois Institute of Technology (IIT) in August, 2011, immediately following nearly five years of experience leading the Purdue School of Materials Engineering as Interim Head and Head. His first faculty appointment was as an Assistant Professor at Purdue University in 1988 after receiving degrees from Case Western Reserve University (CWRU), (B.S. 1981, M.S. 1983) and the University of Michigan (Ph.D. 1987). He was promoted to Associate Professor in 1992, and then promoted to Professor in 1996. Keith Bowman served as a visiting professor and received Alexander von Humboldt stipends for research at the Technical University of Darmstadt, Germany in 1996 and again in 2002. He served as a visiting professor at the University of New South Wales in Sydney, Australia in 2003. From 1996 to 2004 he served as graduate program chair of the Purdue School of Materials Engineering (MSE) during a substantial retooling of the program to more strongly emphasize doctoral degrees. In 2005-06 he served a one-year appointment as Interim Head of MSE and in 2007 was named Head of the Purdue School of Materials Engineering (MSE). He was named a Fellow of the American Ceramic Society in 2000, has held several division and society positions, including becoming a member of the Board of Directors in 2012. In ASME, known as the American Society of Mechanical Engineers, he is a member of the executive committee of the mechanical engineering department heads and chairs (MEDHC). Awards at Purdue University include receiving the MSE Best Teaching Award in 1992 and 1995 and Purdue's highest teaching award, the Charles Murphy Undergraduate Teaching Award in 1995. In 2003 Professor Bowman's name was added to the Purdue Book of Great Teachers. In 2007 he received the Purdue College of Engineering Mentoring Award and he became a Professor of Engineering Education (by courtesy). In 2012 he was invested as the first Duchossois Leadership Professor in the IIT Armour College of Engineering. 
Filtered Gender Diversity Pathways for Domestic and International Doctoral Graduates of United States Electrical Engineering (EE), Computer Engineering (CompE) and Electrical and Computer Engineering (ECE) Programs 
Abstract

Doctoral degree attainment on pathways to a tenured faculty position proceeds through levels wherein persistence differs by gender and race at every level. Using the ASEE database and other sources, this paper describes transitions along the engineering faculty pathway wherein domestic female and male electrical and computer engineering (ECE) undergraduate degree recipients have been producing the surprising result that domestic women are completing ECE doctorates at a higher rate than are domestic men. This suggests that we may have a limited understanding of the motivations and successes in doctoral study for domestic students and that we need to more broadly assess the impacts of our diversity efforts.

Introduction

Slowing or even retreating, progress in gender diversity at the BS level (ASEE, 2013, Bowman 2011,2014 ) shows signs of extending to the level of graduate education through to engineering academia. As gender diversity progress at the Bachelor's degree (BS) level has slowed or even declined, the role of professional societies is clearly of high importance (Robinson 2013; Holm 2013; Johnson 2013; Goldsmith 2013). In spring 2013 the IEEE Computer Society dedicated their monthly magazine Computer to the issue of gender diversity (Prey \& Weaver, 2013). A changed context has been sought that:

“. . you can make a decision to be part of bringing about change by talking with your daughters, nieces, neighbors, and their school counselors about the wonders of computing and how the next generations of computing professionals will have an even more exciting opportunity to change the world."(Prey \& Weaver, 2013)

Navigating from the $\mathrm{BS}$ level and on to $\mathrm{PhD}$ degrees involves a continuously narrowing pathway (Hoag, 2009; Ehrenberg \& Kuh, 2009). Although often characterized as a "pipeline," Bowman (2014) has described it as having characteristics more in line with filtration. Differences in departmental cultures and differences in engineering disciplines are likely amplified by strong disciplinary and sub-disciplinary differences (Fox, 2000; Sonnert et al., 2007). For ECE, separate designations for electrical engineering (EE), computer engineering (CompE) and electrical and computer engineering (ECE) as well as overlap and distinctions from computer science (CS) offer a very challenging context for generalizations as well as data reporting and tracking. Throughout the remainder of this paper the designation ECE will be used for the combined data reported under electrical engineering, computer engineering and electrical and computer engineering headings by ASEE (2013).

Consider the differential outcomes shown in Figure 1 and Table 1 (see also Bowman, 2014). There was approximately one new domestic engineering assistant professor in 2012 for every five thousand graduating high school seniors in 2000, a year in which there were about three million high school graduates. Broken down by gender, this ratio is approximately 1 to 10,000 for females and 1 to 3,000 for males. For ECE, which comprises about twenty-three percent of tenure and tenure-track engineering faculty and may have a slightly lower fraction of US born faculty due to a historically high fraction of foreign doctorates, about one hundred-twenty domestic engineering assistant professors are hired every year with about twenty-five per year 
being female. The electrical engineering devices most similar in scaling to this pathway to an engineering academic career are probably filters and not pipelines.

This paper is focused on the connection between $\mathrm{BS}$ and $\mathrm{PhD}$ degree production in the context of gender equity and domestic versus international students with emphasis on recent demographic data reported for ECE compared to engineering overall. Data used here does not include computer science due to year-to-year variability in reporting by a number of institutions and variable situations in administrative locations, including in separate science or applied science colleges. ECE was chosen for comparison here based on the large numbers of degrees granted and the relatively low fraction of domestic women completing BS degrees.
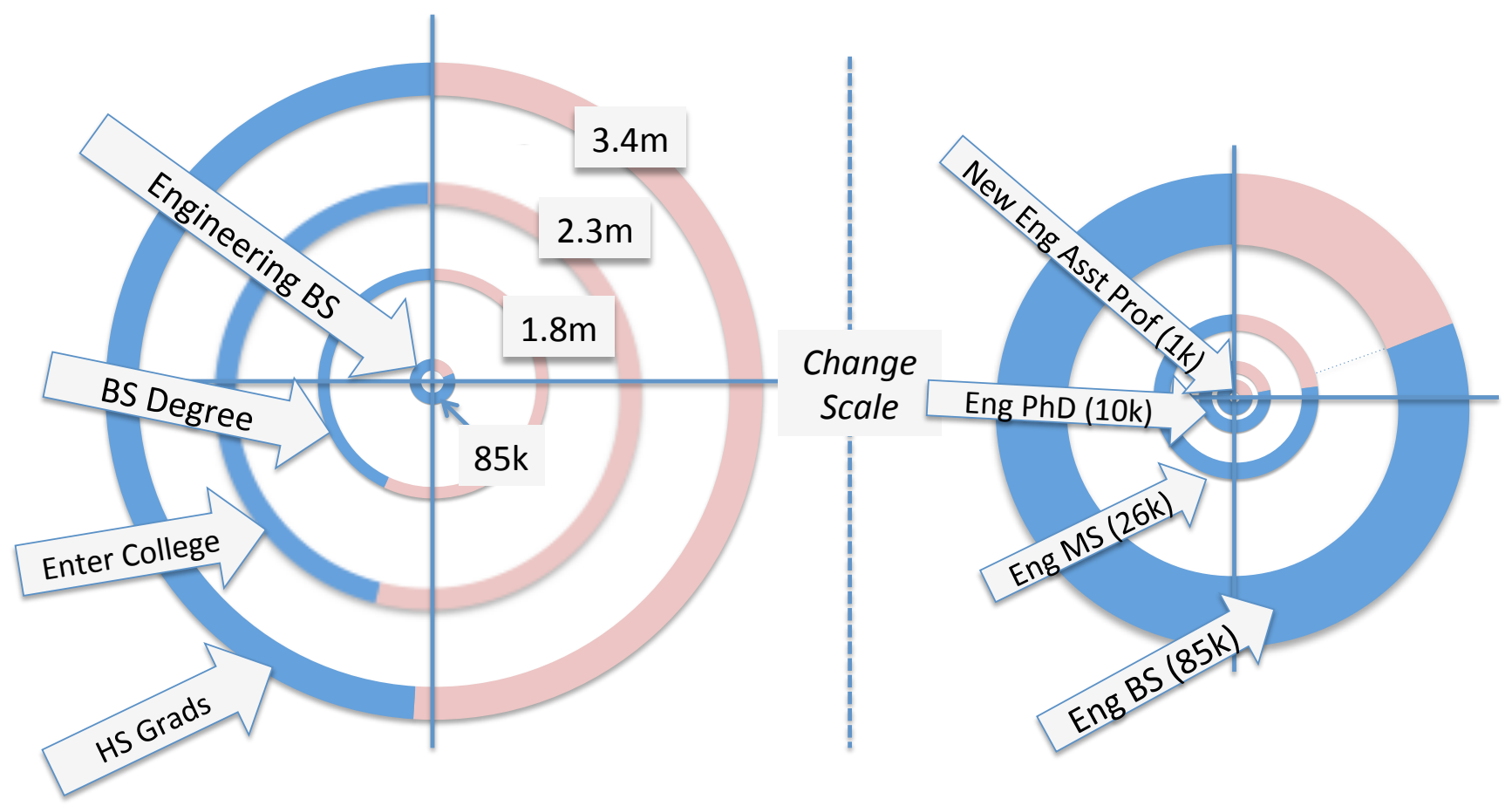

Figure 1 Data for US individuals entering each stage of the pathways towards becoming an engineering assistant professor in 2012 with blue and pink indicating the fractions of male and female, respectively. The scale of the figure changes going from left to right with the outer diameter of each ring showing the relative numbers at each level. Engineering BS is the smallest ring on the left side and the largest ring on the right.

Table 1 Gender Fractions for each Stage shown in Figure 1

\begin{tabular}{|r|c|c|c|c|c|c|c|}
\hline & $\begin{array}{c}\text { High } \\
\text { School } \\
\text { Graduate }\end{array}$ & $\begin{array}{c}\text { Enter } \\
\text { College }\end{array}$ & $\begin{array}{c}\text { BS } \\
\text { Degree }\end{array}$ & $\begin{array}{c}\text { Eng BS } \\
\text { Degree }\end{array}$ & $\begin{array}{c}\text { Eng MS } \\
\text { Degree }\end{array}$ & $\begin{array}{c}\text { Eng PhD } \\
\text { Degree }\end{array}$ & $\begin{array}{c}\text { New Asst } \\
\text { Professor }\end{array}$ \\
\hline Female & $51 \%$ & $54 \%$ & $57 \%$ & $19 \%$ & $23 \%$ & $22 \%$ & $23 \%$ \\
\hline Male & $49 \%$ & $46 \%$ & $43 \%$ & $81 \%$ & $77 \%$ & $78 \%$ & $77 \%$ \\
\hline
\end{tabular}

Data from NCES (2012) and ASEE (2013). 


\section{Context}

The last four years have shown strong growth in US BS degree and $\mathrm{PhD}$ production, as well as enrollment, for engineering disciplines overall as shown in Figure 2 (ASEE, 2013). Throughout the past decade ECE BS degrees have declined in number and even more so in the fraction of overall engineering degrees (see Table 2, Figure 3 and Bowman 2014). In the past decade, most other engineering disciplines have increased in BS output with aerospace engineering nearly doubling in degree output while biomedical engineering more than tripled (ASEE 2013, Bowman 2011). The aggregate of BS degrees for ECE disciplines have decreased by nearly 3000 degrees or $17 \%$. This has meant that ECE disciplines which comprised nearly $29 \%$ of engineering BS degrees in 2002 now comprise less than $19 \%$ of engineering BS degrees in 2012.

Table 2 Degree Production by Gender for EE, CompE, and ECE ASEE Categories

\begin{tabular}{|r|c|c|c|c|c|c|c|c|}
\hline \multirow{2}{*}{} & \multicolumn{2}{|c|}{ EE } & \multicolumn{2}{c|}{ CompE } & \multicolumn{2}{c|}{ ECE } & \multicolumn{2}{c|}{ Total } \\
\cline { 2 - 9 } & BS & PhD & BS & PhD & BS & PhD & BS & PhD \\
\hline 2002 female & 1648 & 77 & 574 & 6 & 506 & 96 & 2728 & 179 \\
\hline 2012 female & 1278 & 199 & 311 & 35 & 321 & 189 & 1910 & 423 \\
\hline change & $-23 \%$ & $158 \%$ & $-46 \%$ & $483 \%$ & $-37 \%$ & $96.9 \%$ & $-30 \%$ & $136.3 \%$ \\
\hline 2002 male & 8956 & 548 & 4163 & 70 & 2890 & 681 & 16,009 & 1299 \\
\hline 2012 male & 8799 & 927 & 3364 & 213 & 2105 & 1008 & 14,268 & 2148 \\
\hline change & $-2 \%$ & $69 \%$ & $-19 \%$ & $204 \%$ & $-27 \%$ & $48.0 \%$ & $-11 \%$ & $65.4 \%$ \\
\hline & & & & & & & & \\
\hline 2002 all & 10,604 & 625 & 4737 & 76 & 3396 & 777 & 18,737 & 1478 \\
\hline 2012 all & 10,077 & 1126 & 3675 & 248 & 2426 & 1197 & 16,178 & 2571 \\
\hline change & $-5 \%$ & $80 \%$ & $-22 \%$ & $226 \%$ & $-29 \%$ & $54.1 \%$ & $-14 \%$ & $74.0 \%$ \\
\hline
\end{tabular}

Data ASEE (2013).

Information on pathways and persistence to BS degrees for ECE is overall fairly limited, but the best information provided by Lord and coworkers (2009a, 2009b, 2010, 2011, 2013) shows that there are some differences in persistence for race and gender. But, as Lord and coworkers indicate, the most important factor is

not a problem of persistence; rather, it is the result of fewer women enrolling in engineering compared with other majors. p.839 (Lord et al., 2010)

Overall engineering $\mathrm{PhD}$ degree production has increased by more than $75 \%$ since 2002 growing from just under 6000 to about 10,000 $\mathrm{PhD}$ degrees in 2012 (Bowman, 2014). ECE PhD production has grown similarly, consistently producing about 24 to $26 \%$ of the US engineering PhD degrees throughout the last decade. Data in Table 2 and Figure 3 shows that ratio of BS to PhD degrees granted by ECE programs in 2012 is about seven-to-one, or about the same ratio as for all engineering disciplines. In 2002 this ratio was nearly thirteen-to-one due to much larger $\mathrm{BS}$ degree production and lower $\mathrm{PhD}$ production. In contrast, the other large engineering discipline, mechanical engineering, has a current $\mathrm{BS}$ to $\mathrm{PhD}$ ratio of over fifteen (Bowman, 2014). 

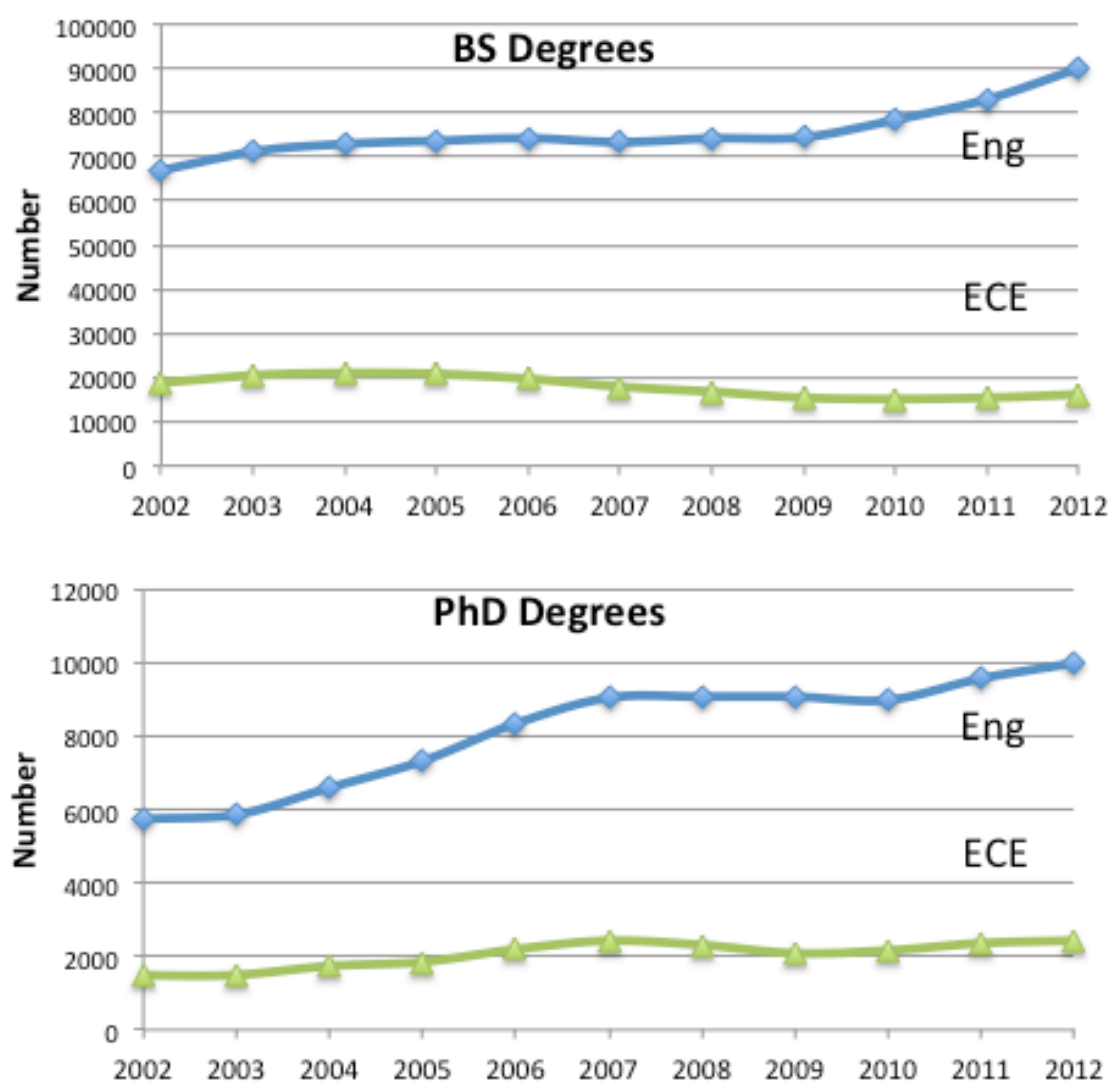

Figure 2 United States (a) BS degree production and (b) $\mathrm{PhD}$ degree production for engineering and ECE from 2002 until 2012 (data from ASEE, 2013).

Diversity in Gender and Nationality at the Bachelor's and Doctoral Levels

A modest decline in the fraction of women earning BS degrees in engineering was accompanied by a steady increase in the fraction of women earning engineering $\mathrm{PhDs}$ across the past decade (Bowman, 2014). For the ECE disciplines the decline in the number and fraction of female BS degrees was substantial. Despite some recent recovery, the number of female BS degrees for the ECE disciplines in 2012 was $30 \%$ less than in 2002 while the contemporaneous decline in male BS degrees was $11 \%$. This resulted in a decrease in the female fraction of BS degrees from 14.6 to $11.3 \%$ as shown in Table 3 . At the same time, doctoral attainment for ECE overall has increased tremendously with very strong growth of PhDs earned by women. For the ECE disciplines the increase in female $\mathrm{PhDs}$ more than doubled while male $\mathrm{PhDs}$ increased by about $65 \%$. This resulted in an increase in the fraction of female $\mathrm{PhD}$ degrees from 12.1 to $16.5 \%$. By 2012, the fraction of female $\mathrm{PhD}$ degrees was well ahead of the female BS degree fraction.

Table 3 Changes in Female Fractions for EE, CompE and ECE ASEE Categories

\begin{tabular}{|r|c|c|c|c|c|c|c|c|}
\hline \multirow{2}{*}{} & \multicolumn{2}{|c|}{ EE } & \multicolumn{2}{c|}{ CompE } & \multicolumn{2}{c|}{ ECE } & \multicolumn{2}{c|}{ Overall } \\
\cline { 2 - 9 } & BS & PhD & BS & PhD & BS & PhD & BS & PhD \\
\hline 2002 & $15.5 \%$ & $12.3 \%$ & $12.1 \%$ & $7.9 \%$ & $14.9 \%$ & $12.4 \%$ & $14.6 \%$ & $12.1 \%$ \\
\hline 2012 & $11.9 \%$ & $17.7 \%$ & $8.5 \%$ & $14.1 \%$ & $13.2 \%$ & $15.8 \%$ & $11.3 \%$ & $16.5 \%$ \\
\hline Change & $-3.7 \%$ & $5.4 \%$ & $-3.7 \%$ & $6.2 \%$ & $-1.7 \%$ & $3.4 \%$ & $-3.2 \%$ & $4.3 \%$ \\
\hline
\end{tabular}

Data ASEE (2013). 

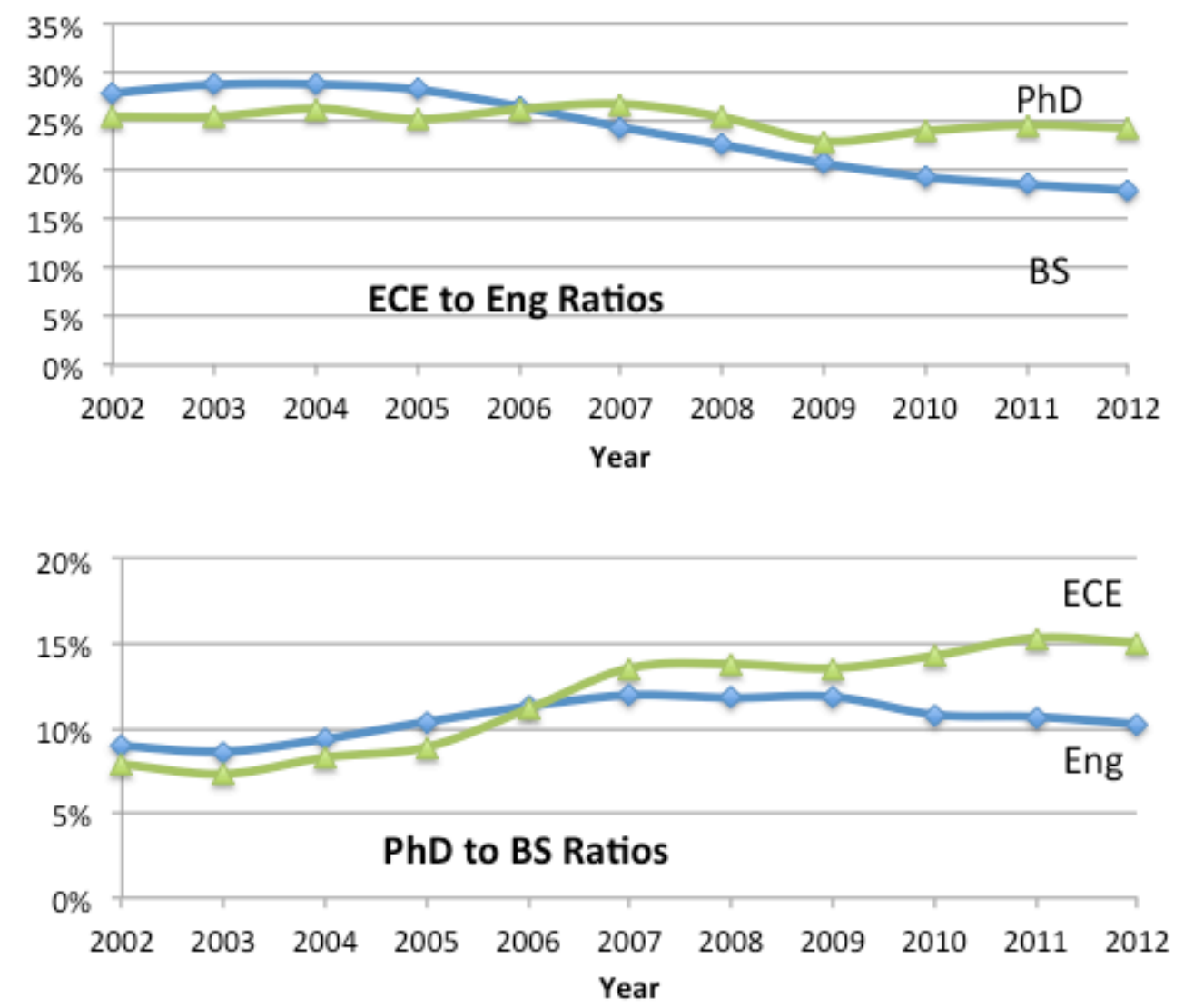

Figure 3 (a) Fraction of total engineering BS degrees and PhD degrees earned in ECE. (b) Fraction of PhD degrees to BS degrees for engineering and ECE (data from ASEE, 2013).

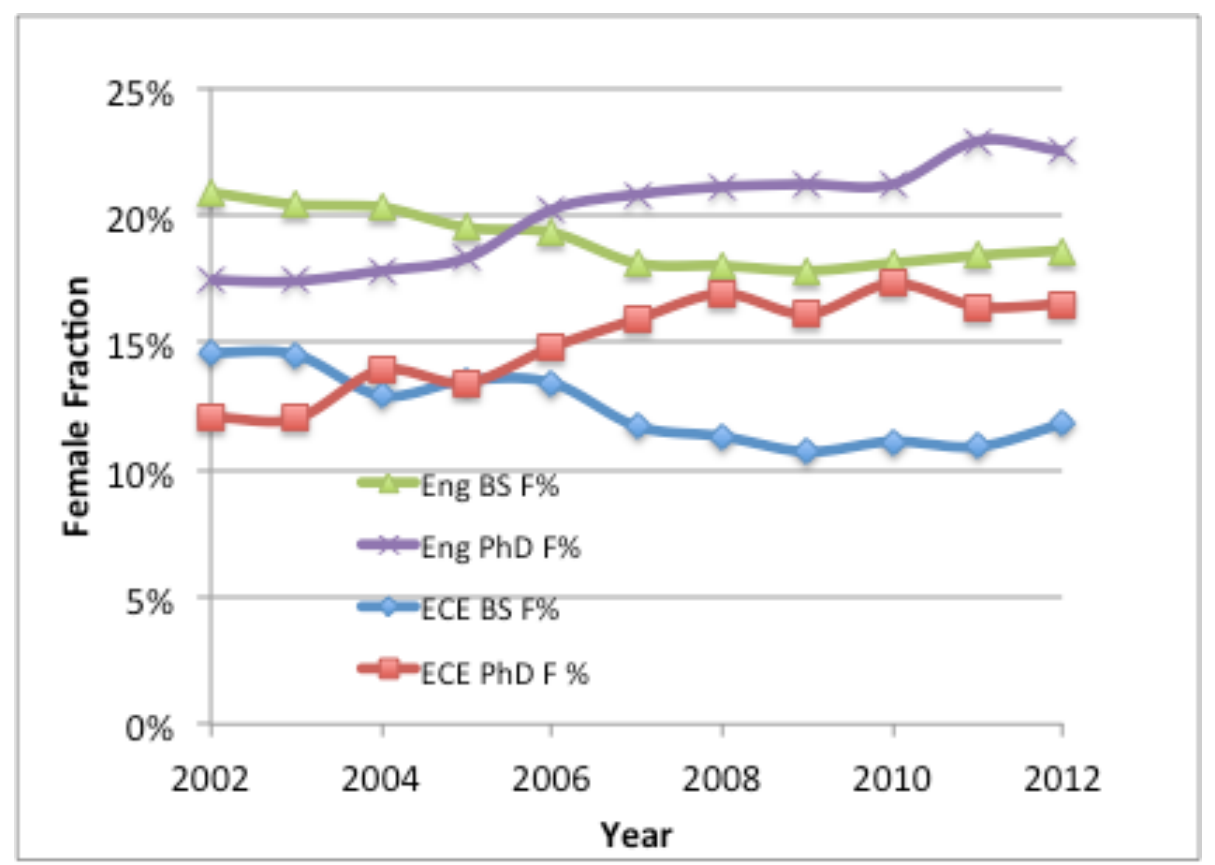

Figure 4 Fraction of engineering and ECE BS degrees and $\mathrm{PhD}$ degrees earned by women (data from ASEE, 2013). 
Figure 4 shows that 2006 was the first year that for engineering overall the fraction of women earning $\mathrm{PhD}$ degrees exceeded the fraction of women earning $\mathrm{BS}$ degrees. This difference continued to increase in subsequent years with 2011 showing nearly $23 \%$ of engineering $\mathrm{PhD}$ degrees being earned by women while in the same year only about $18 \%$ of BS degrees were earned by women. Figure 4 also demonstrates that ECE had a nearly contemporaneous crossover wherein the fraction of women earning $\mathrm{PhD}$ degrees exceeds the female $\mathrm{BS}$ degree fraction.

In an assessment of data right at this crossover point, Ferreira (2009) lamented the slow progress in gender diversity at the doctoral level and also suggested that the increases in gender diversity for STEM doctoral attainment had been due to increases in female doctorates earned by foreign nationals. Figure 5 shows that for the past decade the fraction of foreign nationals for ECE has been between 60 and $70 \%$ of doctoral degrees, which is slightly ahead of engineering overall. Table 4 and Figure 6 show that the fraction of female $\mathrm{PhD}$ degrees for both domestic and foreign students has been increasing steadily in recent years and that the female fraction among domestic students is higher than for foreign students. Since 2006, the final year of data analyzed by Ferreira (2009), the number of female domestic PhDs for ECE disciplines increased from 82 to 163 whereas the number of female foreign $\mathrm{PhDs}$ increased from 249 to 260. This demonstrates that recent gains in gender diversity for ECE occurred predominantly through increased in domestic PhDs. For domestic students the female fraction of $\mathrm{PhD}$ degrees is more than fifty percent greater than the female fraction for BS degrees.

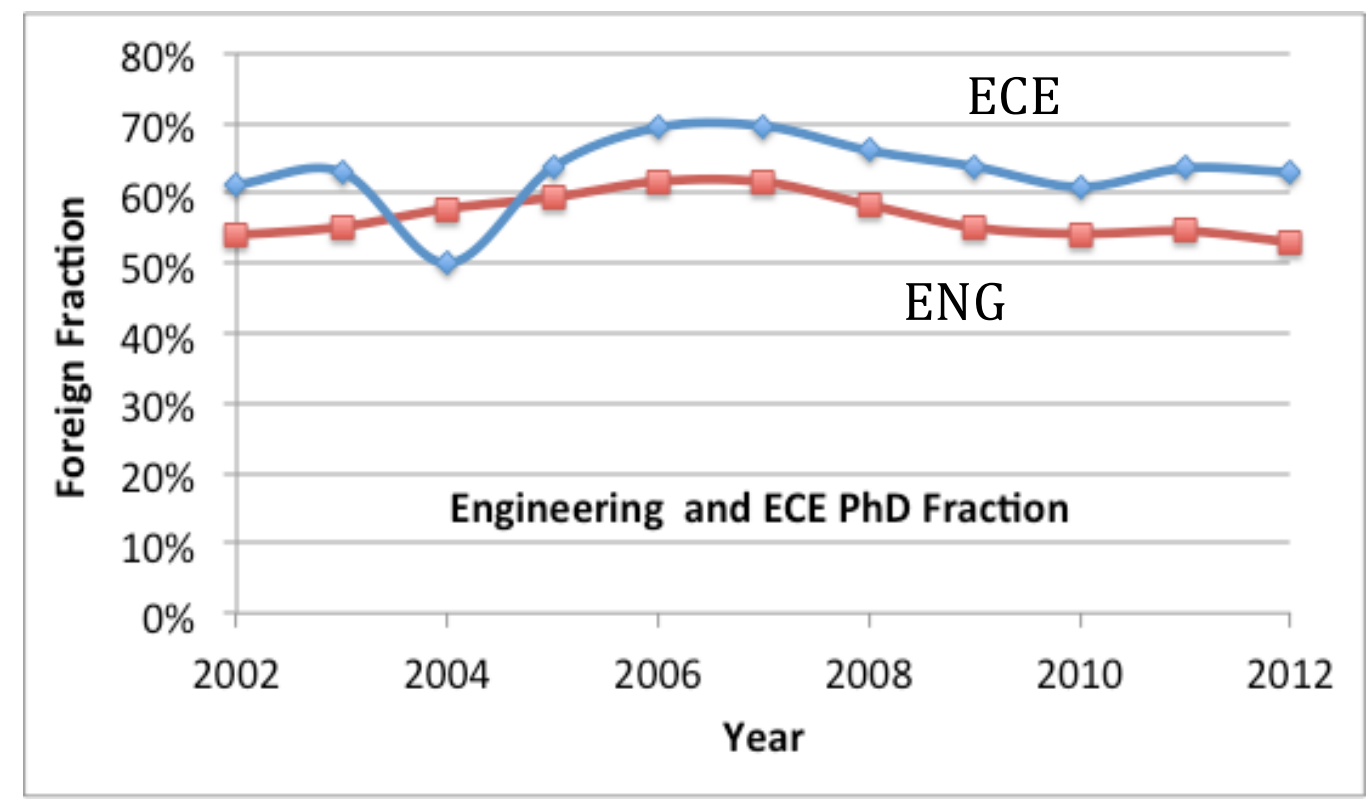

Figure 5 Fraction of ENG and ECE PhD degrees earned by foreign national students. (ASEE, 2013).

The fraction of domestic women receiving all engineering doctoral degrees has remained between 20 percent and 40 percent above the fraction of women receiving engineering BS degrees for the last several years. Across the past five years the ratio between domestic 
engineering $\mathrm{PhD}$ degrees and $\mathrm{BS}$ degrees was about 1 to 15 for women and about 1 to 18 for men (see Bowman, 2014). For the same period the ratio between domestic ECE PhD degrees and BS degrees is about 1 to 12 for women and about 1 to 18 for men.

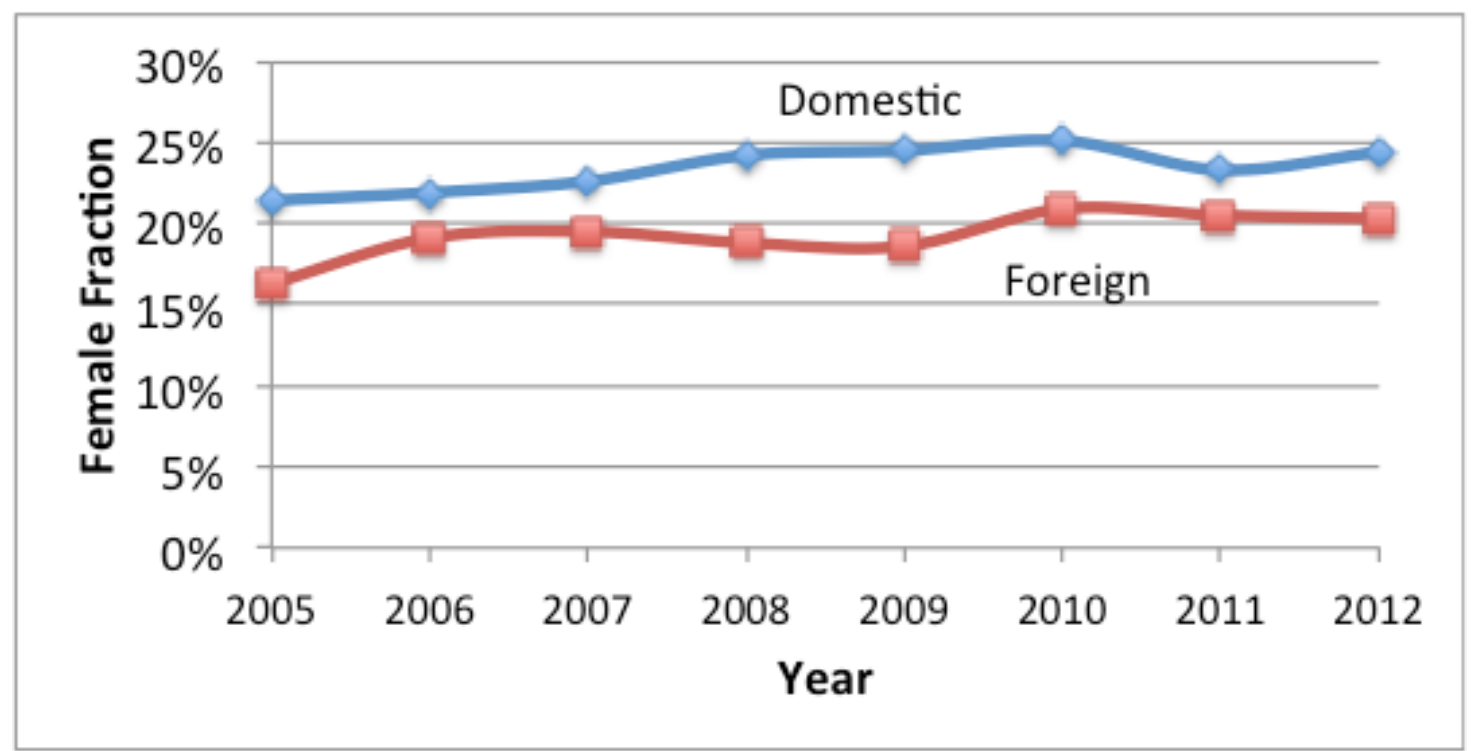

Figure 6 Fraction of ECE PhD degrees earned by domestic and foreign national women (ASEE, 2013).

Implications

Persisting to completion of a doctorate degree involves a number of complex factors that have received only modest attention (Bowman, 2014). Academic advising, personal and family issues, the availability and attractiveness of employment opportunities at the BS and MS level, financial obligations and the availability of financial support are all factors that have been considered (Gardener, 2009; Barnes, 2012, Meyers et al., 2012).

The impacts of transformative graduate education programs at specific institutions have not apparently resulted in systemic, positive impacts (Kniola et al., 2012, Bowman, 2014), but differences in performance between women in men in undergraduate education may be a factor (see Orr, et al., 2011). They showed that for engineering overall women had a mean GPA of 2.91 whereas men had a GPA of 2.75. One might speculate that this difference in GPA could increase the likelihood that domestic women attend graduate school. Unfortunately, for EE there is no statistically significant difference in GPA and for CompE men perform better than women, suggesting deeper analysis might be necessary.

In analyses of undergraduate research experience (URE) data, it is clear that females appear to have been participating in UREs at twice the rate of male undergraduate engineers (Russell et al., 2006, 2007, Hancock and Russell, (2008), Bowman, 2014). This higher participation rate of women than their representation as undergrads may be having a positive impact on $\mathrm{PhD}$ attainment. This suggests that further study of ECE-specific URE programs might be warranted.

Relative to the BS level, $\mathrm{PhD}$ programs are strongly impacted by recruiting, candidate screening and financial support controlled by departments and individual faculty (Fox, 2000, Bowman, 
2014). ECE programs and individual faculty have independent control over recruiting and mentoring graduate students in their research groups as they do for URE students. The recent growth in female doctoral attainment, particularly for domestic ECE students, is an area ripe for further investigation. And, if we had a better understanding of what is producing this positive outcome, it might provide insight that could be positively applied to the K-12 level.

Conclusions

Advancing $\mathrm{PhD}$ attainment of domestic students across all races and ethnicities is essential towards producing eligible employees for many defense and non-defense national laboratory positions, but in also ensuring that some degree of balance is maintained in the proportion of domestic and foreign students receiving advanced degrees. Improving our understanding of how the professional identities of female engineering $\mathrm{PhD}$ recipients, and in particular, those in the most male-dominated engineering fields like ECE develop and differ from other women and men could provide powerful insight into persistence at every level.

Table 4 Comparison of ENG and ECE Degree Attainment in 2012

\begin{tabular}{|r|c|c|c|c|}
\hline Discipline & $\begin{array}{c}\text { Domestic BS } \\
\text { Female Fraction }\end{array}$ & $\begin{array}{c}\text { Romestic PhD } \\
\text { Female Fraction }\end{array}$ & $\begin{array}{c}\text { Domestic } \\
\text { BS to PhD }\end{array}$ & $\begin{array}{c}\text { Foreign PhD } \\
\text { Female Fraction }\end{array}$ \\
\hline ECE & $11.8 \%$ & $17.1 \%$ & 1.5 & $16.1 \%$ \\
\hline ENGINEERING & $18.9 \%$ & $24.4 \%$ & 1.3 & $20.3 \%$ \\
\hline
\end{tabular}

Data from ASEE (2013)

References

Amelink, C. T., \& Creamer, E. G. (2010), Gender differences in elements of the undergraduate experience that influence satisfaction with the engineering major and the intent to pursue engineering as a career. Journal of Engineering Education, 99(1), 81-92.

Ampaw, F. D., \& Jaeger, A. J. (2011), Understanding the factors affecting degree completion of doctoral women in the science and engineering fields. New Directions for Institutional Research, 2011(152), 59-73.

ASME Diversity and Inclusion Strategy Committee, (2012), https://www.asme.org/getmedia/a75fbf4b-164a-4738-b429d6bc42d714b8/PS1205_Diversity_Inclusion_Science_Technology_Mathematics.aspx

ASEE 2013, American Society for Engineering Education Database and Profile, www.asee.org.

Barnes, B. J., \& Randall, J. (2012), Doctoral student satisfaction: An examination of disciplinary, enrollment, and institutional differences. Research in Higher Education, 53(1), 47-75.

Beddoes, K. (2011). Engineering Education Discourses on Underrepresentation: Why Problematization Matters. International Journal of Engineering Education,27(5), 1117. 
Bowman, K. J. (2011). Potential impacts of creating biomedical engineering programs on gender distribution within leading engineering colleges. Journal of Diversity in Higher Education, 4(1), 51.

Bowman, K. J., (2014) Differential Filtering in Gender Diversity Pathways for Domestic and International Doctoral Graduates of United States Mechanical Engineering Programs, International Journal of Gender, Science and Technology, submitted February, 2014.

Ehrenberg, R. G., \& Kuh, C. V. (Eds.) (2009), Doctoral education and the faculty of the future. Cornell University Press.

Erickson, S. K. (2012), Women Ph. D. students in engineering and a nuanced terrain: Avoiding and revealing gender. The Review of Higher Education, 35(3), 355-374.

Ferreira, M. M. (2009). Trends in women's representation in science and engineering. Journal of Women and Minorities in Science and Engineering, 15(3).

Fox, M. F. (2000), Organizational environments and doctoral degrees awarded to women in science and engineering departments. Women's Studies Quarterly,28(1/2), 47-61.

Gardner, S. K. (2009), Conceptualizing success in doctoral education: Perspectives of faculty in seven disciplines. The Review of Higher Education,32(3), 383-406.

Goldsmith, Marc, (2013), Diversity: A Valuable Engineering Commodity, ASME President Statement https://www.asme.org/about-asme/news/letters-official-statements/the-asme-president-february$\underline{201}$

Hancock, M. P., \& Russell, S. H., (2008), A Draft Report: Research experiences for undergraduates (reu) in the directorate for engineering (eng): 2003-2006 Participant Survey, National Science Foundation Report, under Contract GS10F0554N/06D1403 Downloaded August 31, 2013, http://csted.sri.com/sites/default/files/reports/REU_ENG_20032006_Participant_Survey_Report.pdf

Hoag, H. (2009), Women at the top: US academies track women's success along the academic pipeline, Nature, Vol. 459, p. 1021, www.nature.com/naturejobs/2009/090618/ full/nj72491021a.html

Holm, E. (2013), Planting the Seeds of Diversity, JOM, July, Volume 65, Issue 7, p 807

Johnson, P. A. (2013). The State of Women in Civil Engineering in the US and the Role of ASCE. Journal of Professional Issues in Engineering Education and Practice.

Kniola, D., Chang, M., \& Olsen, D. (2012). Transformative graduate education programs: an analysis of impact on STEM and non-STEM Ph. D. completion.Higher Education, 63(4), 473495. 
Lord, S. M., Brawner, C. E., Camacho, M. M., Layton, R. A., Ohland, M. W., \& Wasburn, M. H. (2009a, October). Work in progress-engineering students' disciplinary choices: Do race and gender matter?. In Frontiers in Education Conference, 2009. FIE'09. 39th IEEE (pp. 1-2). IEEE.

Lord, S. M., Camacho, M. M., Layton, R. A., Long, R. A., Ohland, M. W., \& Wasburn, M. H. (2009b). Who's persisting in engineering? A comparative analysis of female and male Asian, black, Hispanic, Native American, and white students.Journal of Women and Minorities in Science and Engineering, 15(2).

Lord, S. M., Camacho, M. M., Layton, R. A., \& Ohland, M. W. (2010, April). Who enrolls in electrical engineering? A quantitative analysis of USA student trajectories. In Education Engineering (EDUCON), 2010 IEEE (pp. 839-844). IEEE.

Lord, S. M., Layton, R. A., \& Ohland, M. W. (2011). Trajectories of Electrical Engineering and Computer Engineering students by race and gender. Education, IEEE Transactions on, 54(4), 610-618.

Lord, S. M., Layton, R. A., Ohland, M. W., \& Orr, M. K. (2013, October). Student demographics and outcomes in Electrical and Mechanical Engineering. In Frontiers in Education Conference, 2013 IEEE (pp. 57-63). IEEE.

Meyers, K. L., Ohland, M. W., Pawley, A. L., Silliman, S. E., \& Smith, K. A. (2012). Factors relating to engineering identity. Global Journal of Engineering Education,14(1).

National Center for Education Statistics (2012), http://nces.ed.gov/fastfacts/display.asp?id=372 downloaded August 18, 2013.

National Science Foundation, Survey of Earned Doctorates, http://nsf.gov/statistics/gradpostdoc/ downloaded August 18, 2013.

Nerad, Maresi, (2009) "Confronting Common Assumptions: Designing Future-Oriented Doctoral Education" in Doctoral Education and the Faculty of the Future edited by R. G. Ehrenberg and C. V. Kuh, Cornell University Press, pp. 80-89.

Nettles, M. T., \& Millett, C. M. (2006). Three magic letters: Getting to Ph.D. Baltimore, MD: The Johns Hopkins University Press.

Olivas, M. A. (2009) "What the "War on Terror" has meant for U.S. Colleges and Universities" in Doctoral Education and the Faculty of the Future edited by R. G. Ehrenberg and C. V. Kuh, Cornell University Press, pp. 80-89.

Orr, M. K., Ngambeki, I., Long, R. A., \& Ohland, M. W. (2011, October). Performance trajectory of students in the engineering disciplines. In Frontiers in Education Conference (FIE), 2011 (pp. S3H-1). IEEE.

Prey, J. C., \& Weaver, A. C. A. (2013). Fostering Gender Diversity in Computing. Computer, 46(3), 22-23. 
Robinson, Lynne, (2013), United in our differences: Changing the face of MSE," JOM, TMS, June, pp. 808-829.

Russell, S. H., Hancock, M. P., \& McCullough, J. (2006). Evaluation of NSF support for undergraduate research opportunities. EVALUATION.

Russell, S. H., Hancock, M. P., \& McCullough, J. (2007). Benefits of undergraduate research experiences. Science(Washington), 316(5824), 548-549.

Simpson, Patricia (2012) Personalities and Pipelines: Exploring the Role of Personality in Student Self-selection Into Stem Majors (Doctoral dissertation, University of North Texas). http://digital.library.unt.edu/ark:/67531/metadc115158/m2/1/high_res_d/dissertation.pdf Downloaded August 18, 2013.

Sonnert, G., Fox, M. F., \& Adkins, K. (2007), Undergraduate Women in Science and Engineering: Effects of Faculty, Fields, and Institutions Over Time*. Social Science Quarterly, 88(5), 1333-1356. 